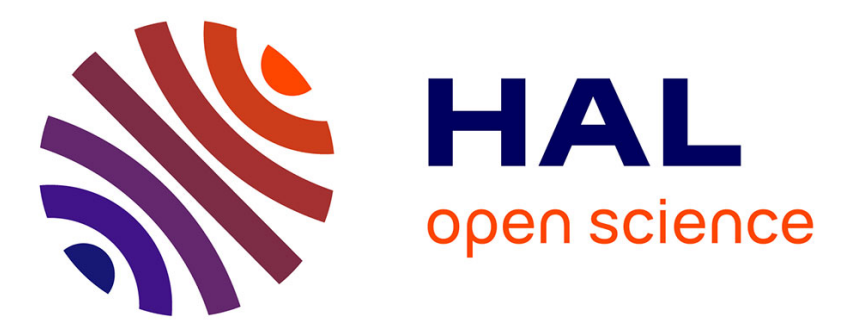

\title{
Carbon Nanotubes Integration on Silicon
}

\author{
E. Durán-Valdeiglesias, W Zhang, H C Hoang, C Alonso-Ramos, S Serna, X \\ Le Roux, E Cassan, L Vivien, F Sarti, U Torrini, et al.
}

\section{To cite this version:}

E. Durán-Valdeiglesias, W Zhang, H C Hoang, C Alonso-Ramos, S Serna, et al.. Carbon Nanotubes Integration on Silicon. Progress in Electromagnetics Research Symposium (Piers), Aug 2016, shanghai, China. pp.8 - 11, 10.1109/PIERS.2016.7734732 . cea-01635427

\section{HAL Id: cea-01635427 https://hal-cea.archives-ouvertes.fr/cea-01635427}

Submitted on 15 Nov 2017

HAL is a multi-disciplinary open access archive for the deposit and dissemination of scientific research documents, whether they are published or not. The documents may come from teaching and research institutions in France or abroad, or from public or private research centers.
L'archive ouverte pluridisciplinaire HAL, est destinée au dépôt et à la diffusion de documents scientifiques de niveau recherche, publiés ou non, émanant des établissements d'enseignement et de recherche français ou étrangers, des laboratoires publics ou privés. 


\title{
Carbon Nanotubes Integration on Silicon
}

\author{
E. Durán-Valdeiglesias ${ }^{1}$, W. Zhang ${ }^{1}$, H. C. Hoang ${ }^{1}$, C. Alonso-Ramos ${ }^{1}$, S. Serna ${ }^{1}$, \\ X. Le Roux ${ }^{1}$, E. Cassan ${ }^{1}$, L. Vivien ${ }^{1}$, F. Sarti ${ }^{2}$, U. Torrini ${ }^{2}$, M. Gurioli ${ }^{2}$, M. Balestrieri ${ }^{3}$, \\ A. Keita ${ }^{3}$, A. Filoramo ${ }^{3}$, H. Yang ${ }^{4}$, V. Bezugly ${ }^{4}$, and G. Cuniberti ${ }^{4}$ \\ ${ }^{1}$ Institut d'Electronique Fondamentale (IEF), CNRS UMR 8622 \\ Univ Paris Sud, Université Paris Saclay, F-91405 Orsay, France \\ ${ }^{2}$ European Laboratory for Non-linear Spectroscopy, Department of Physics \\ University of Florence, Sesto Fiorentino, FI 50019, Italy \\ ${ }^{3}$ CEA Saclay, IRAMIS, NIMBE (UMR 3685), LICSEN \\ Bat. 125, F-91191 Gif-sur-Yvette, Franceline 1, France \\ ${ }^{4}$ Institute for Materials Science, Technische Universitaet Dresden, Dresden, Germany
}

\begin{abstract}
Optical interconnects are expected to overcome the copper link bottlenecks. Among the different developed technologies, silicon photonics becomes one of the preferred solutions. Indeed, due to its compatibility with the CMOS platform, silicon photonics is considered as a viable solution for the development of the future generation photonic interconnects. However, the on-chip integration of all photonic and optoelectronic building blocks (sources, modulators and detectors...) on the silicon platform is very complex and is not cost-effective due to the various materials used: Ge for detection, Si for waveguiding and modulators and III-V for lasing. We propose here to use carbon nanotubes (CNTs) integrated into silicon photonics for the development of all optoelectronic devices. Indeed, CNTs are nanomaterials of particular interest in photonics thanks to their fundamental optical properties including near-IR luminescence, Stark effect, Kerr effect and absorption. In consequence, CNTs have the ability to emit, modulate and detect light in the wavelength range of the silicon transparency. Furthermore, they are also considered as an electronic compatible material thanks to the recent advances in nanoelectronics based on CNTs.

Here, we report on the study of the light emission coupling from CNTs into optical resonators implemented on the silicon-on-insulator (SOI) platform including ring resonators, nano-beam cavities, micro-disks.... A theoretical and experimental analysis of the light interaction of CNTs with micro-ring resonators based on slot waveguides and slot photonic crystal heterostructure cavities will be presented.
\end{abstract}

